\title{
Economic analysis of the distributed generation development in northern part of Hebei province
}

\author{
Xinmin $\mathrm{Li}^{1, \mathrm{a}}$, Weidong Shen ${ }^{2, \mathrm{~b}}$, Jianlei $\mathrm{Shi}^{2, \mathrm{c}}$ and Yongxiu $\mathrm{He}^{1, \mathrm{~d}}$ \\ ${ }^{1}$ North China Electric Power University, School of Economics and Management, Beijing, China \\ ${ }^{2}$ State Grid Jibei Electric Power Company Limited Economic Research Institute, Beijing, China \\ alixinmin_tj@163.com, ${ }^{b} 2319669491 @ q q . c o m,{ }^{c} 125522526 @ q q . c o m,{ }^{d}$ yongxiuhe@126.com
}

Keywords: Distributed power; Distributed photovoltaic generation; Economic analysis; Northern part of Hebei province

Abstract: Northern part of Hebei province as an important resource area of solar energy and wind energy will promote distributed power development in the thirteenth Five-Year period vigorously. This paper took a distributed photovoltaic project as an example, and made an economic analysis for the distributed power in the north of Hebei province. The marginal sale price of distributed generation project was calculated on the basis of ensuring $8 \%$ internal rate of return. IRR of project is most sensitive to the change of photovoltaic distributed power sale price, followed by state financial subsidy, and the last is project initial investment.

\section{Introduction}

Wind, solar and biomass energy and other resource are rich in Northern part of Hebei province, which is particularly rich in solar resources. The thirteenth Five-Year Plan of Hebei province renewable energy development made it clear that Hebei province would vigorously develop distributed energy projects adaptation to local conditions, such as solar energy, wind energy, biomass power and natural gas cogeneration and other kinds of distributed generation $[1,2]$. At the same time, the reasonable economic analysis for distributed energy has become one of the focuses of research $[3,4,5,6]$. In addition, the research also evaluated the environmental benefits of distributed generation projects [7, 8].

\section{Economic analysis model of distributed generation project}

In this paper, the photovoltaic distributed generation project is taken as an example to carry on economic analysis on the base of life cycle theory in Northern part of Hebei province. The meaning of relevant parameters in model is shown in Table 1. 
Table1 The remarks of parameters in following model

\begin{tabular}{|c|c|c|c|}
\hline Parameters & Remarks & Parameters & Remarks \\
\hline$Q$ & Annual electric energy production & $\eta$ & The efficiency of the PV system \\
\hline$C_{\text {inv }}$ & Project initial investment & $M$ & Installed capacity of system \\
\hline$C_{\text {ope }}$ & $\begin{array}{c}\text { Annual operation and maintenance } \\
\text { cost }\end{array}$ & $H$ & Annual utilization hours \\
\hline$C_{\text {fin }}$ & Annual financial expense & $n$ & Project life cycle \\
\hline$C_{\text {in }}$ & Annual cash inflow & $C_{\text {out }}$ & Annual cash outflow \\
\hline$P_{0}$ & $\begin{array}{c}\text { Electricity sale price of photovoltaic } \\
\text { distributed power }\end{array}$ & $P_{1}$ & Feed-in Tariff \\
\hline$K$ & $\begin{array}{c}\text { The rate of production back to utility } \\
\text { grid }\end{array}$ & $I R R$ & Internal rate of return of project \\
\hline$t_{1}$ & Added-value tax rate & $C_{\text {npv }}$ & Net present value of project \\
\hline$t_{2}$ & Addition to the added-value tax rate & $B$ & State financial subsidy \\
\hline$t_{3}$ & Income tax rate & $T_{\text {inc }}$ & Income tax \\
\hline
\end{tabular}

The annual generation output of photovoltaic distributed generation system is related to the level of solar resource and the installed capacity of system.

$$
Q=M \times H \times \eta
$$

The annual income of photovoltaic distributed generation project is as follows.

$$
C_{\text {in }}=Q \times B+P_{0} \times Q \times(1-K)+P_{1} \times Q \times K
$$

The annual expenditure of photovoltaic distributed generation project includes operation and maintenance management fee, financial expense and taxes.

$$
C_{\text {out }}=C_{f i n}+C_{o p e}+\frac{P_{0} \times Q \times(1-K)+P_{1} \times Q \times K}{1+t_{1}} \times t_{1} \times\left(1+t_{2}\right)+T_{\mathrm{inc}}
$$

The annual net profit of photovoltaic distributed generation project is as follow.

$$
P_{\text {net }}=C_{\text {fin }}+C_{\text {ope }}+\frac{P_{0} \times Q \times(1-K)+P_{1} \times Q \times K}{1+t_{1}} \times t_{1} \times\left(1+t_{2}\right)-C_{\text {in }}
$$

Therefore, the income tax is shown as follow.

$$
T_{\text {inc }}=\left\{\begin{array}{cc}
P_{\text {net }} \times t_{3} & P_{\text {net }}>0 \\
0 & P_{\text {net }} \leq 0
\end{array}\right.
$$

Assuming that the life cycle life of project is $n$, the formula for calculating the internal rate of return of photovoltaic distributed generation project in the whole life cycle is as follows:

$$
C_{\mathrm{npv}}=\sum_{t=1}^{n}\left[C_{\mathrm{in}}-C_{\text {out }}\right](1+I R R)^{-t}-C_{\mathrm{inv}}=0
$$




\section{Case analysis}

The case study takes the installed capacity $50 \mathrm{~kW}$ photovoltaic distributed generation project as an example, assumes that the proportion of loans for initial investment is $50 \%$. The other data used in calculation are shown in Table 2.

Table 2 The data of parameters in model

\begin{tabular}{|c|c|c|c|}
\hline $\begin{array}{c}\text { Parameter } \\
\mathrm{s}\end{array}$ & Remarks & Units & Data \\
\hline$C_{\text {inv }}$ & Project initial investment & yuan & 10260 \\
\hline$C_{\text {ope }}$ & Annual operation and maintenance cost & yuan & 28215 \\
\hline$C_{\text {fin }}$ & Annual financial expense & yuan & 25 \\
\hline$K$ & The rate of production back to utility grid & $\%$ & 0.3634 \\
\hline$P_{1}$ & Feed-in Tariff & yuan/kWh & 75 \\
\hline$\eta$ & The efficiency of the PV system & $\%$ & 50 \\
\hline$M$ & Installed capacity of system & $\mathrm{kW}$ & 3200 \\
\hline$H$ & Annual utilization hours & year & 25 \\
\hline$n$ & Project life cycle & $\%$ & 17 \\
\hline$t_{1}$ & Added-value tax rate & $\%$ & 8 \\
\hline$t_{2}$ & Addition to the added-value tax rate & $\%$ & 25 \\
\hline$t_{3}$ & Income tax rate & $\%$ & $5 \%$ \\
\hline$i$ & discount rate & & \\
\hline
\end{tabular}

The sales price of flat period in Hebei province is assumed to be sales price for photovoltaic distributed generation, and the price of resident users is 0.52 yuan $/ \mathrm{kWh}$, the commercial users is 0.6626 yuan $/ \mathrm{kWh}$, the large industrial users is 0.5476 yuan $/ \mathrm{kWh}$. Based on the above data, the internal rate of return (IRR)and dynamic recovery period of photovoltaic distributed generation project in in the northern part of Hebei province are shown in Table 3.

Table 3 The internal rate of return and dynamic recovery period of project

\begin{tabular}{|c|c|c|c|}
\hline Index/The types of user & Resident users & Commercial users & Industry users \\
\hline The internal rate of return & $7.98 \%$ & $10.47 \%$ & $8.47 \%$ \\
\hline Dynamic recovery period(year) & 14.21 & 10.97 & 13.46 \\
\hline
\end{tabular}

Through the above calculation results, the internal rate of return reaches $8 \%$ when the sales targets are commercial users and industry users, slightly less than $8 \%$ for residential users. In order to ensure the profit of investors, the sale price should reach $0.5215 \mathrm{yuan} / \mathrm{kWh}$ in the northern part of Hebei province. When the sale price exceeds the marginal price, the internal rate of return meets the requirement 8\%. As shown in Fig.1, when the electricity price is higher than Feed-in Tariff, the lower rate is, the higher internal rate of return is. 


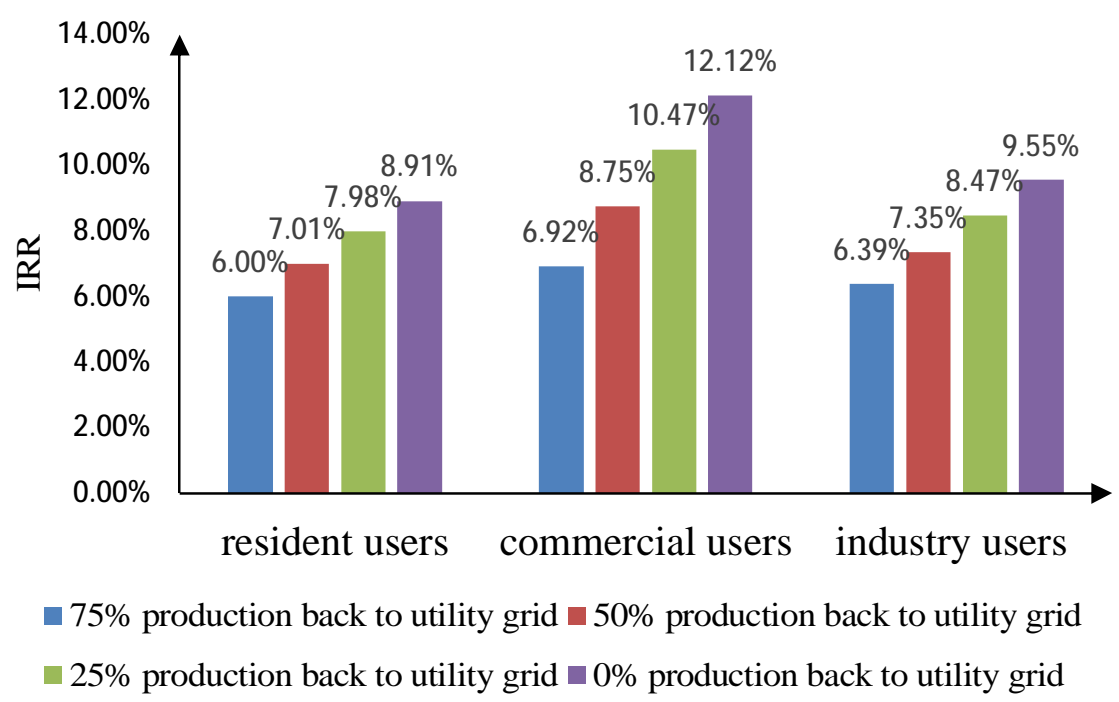

Fig.1 The IRR in different rate of production back to utility grid

The following sensitivity analysis mainly selects the main influencing factors of electricity sale price, state financial subsidy and project initial investment to anaylsis.

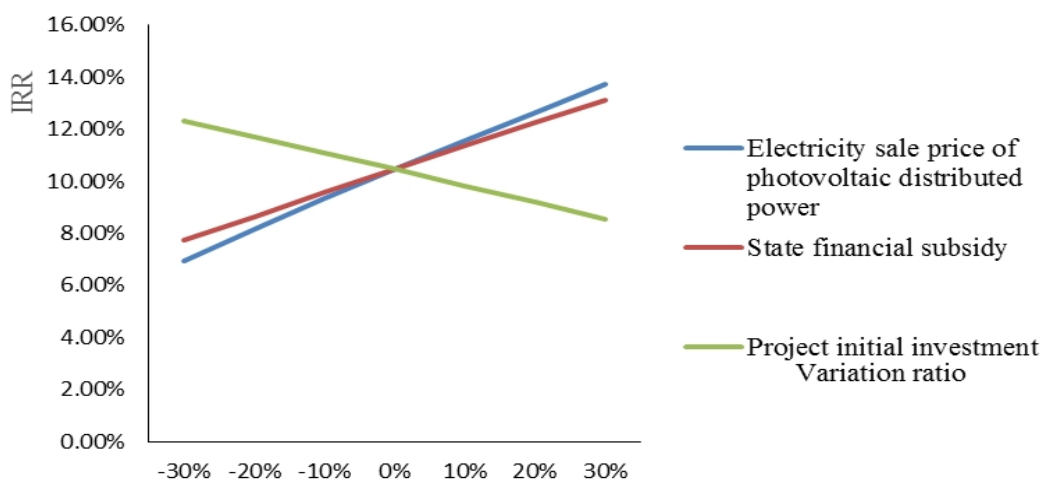

Fig.2 The sensitivity analysis of different influencing factors

\section{Conclusions}

(1)Northern part of Hebei province as a rich solar resource region, it is very suitable for the development of photovoltaic distributed generation. Taking local electricity price as sale price of photovoltaic distributed generation, the internal rate of return is the largest when customer is commercial users, followed by large industrial users, the smallest is resident users. In order to ensure the profit of investors, the sale price of photovoltaic distributed generation project should be more than $0.5215 y u a n / \mathrm{kWh}$ in the northern part of Hebei province.

(2) The rate of production back to utility grid of photovoltaic distributed generation system has a huge impact on investment income. When the electricity price is higher than Feed-in Tariff, the lower rate is, the higher internal rate of return is, it can be more conducive to recover the investment for investors. IRR of project is most sensitive to the change of photovoltaic distributed power sale price, followed by state financial subsidy, and the last is project initial investment.

\section{Acknowledgements}

The work described in this paper was supported by the research grant from of the State Grid Electric Power Corporation in China. 


\section{References}

[1] P.K. Liu, Z.F. Tan, "How to develop distributed generation in China: In the context of the reformation of electric power system", Renewable and Sustainable Energy Reviews,Vol.66, pp.10-22, 2016.

[2] X. Luo, J.P. Liu, "Economic analysis of residential distributed PV project" in Chinese, $\mathrm{Xi}^{\prime}$ an Univ. of Arch. \& Tech.(Natural Science Edition), vol.47, pp. 437-441,2015.

[3] The Thirteenth Five-Year Plan of Hebei Province Renewable Energy Development, Information on http://info.hebei.gov.cn, 2016.

[4] H.Q. Shao, J. Zhang, W. Zhang, "Economy and Policy Analysis of Distributed Photovoltaic Generation" in Chinese, Electric power construction, Vol.35, pp.51-57, 2014.

[5] Q.H. Wang, S.Z. Wei, L. Yang, etc., "Application of the Concept of Real Options to Analyze the Economic Value of Natural Gas Distributed Energy Projects" in Chinese, Management and Administration, Vol.10, pp. 36-38, 2013.

[6] Q. Jin, Z.N. Shi, J.R. Li, etc., "National Economic Evaluation of Photovoltaic Generation" in Chinese, Electric power construction, Vol.34, pp. 87-90, 2013.

[7] K.J. Qian, Y. Yuan, X.D. Shi, etc., "Environmental Benefits Analysis of Distributed Generation" in Chinese, Proceedings of the CSEE, Vol.28, pp.11-15, 2008.

[8] F. Zhang, H. Deng, R. Margolis, etc., "Analysis of distributed-generation photovoltaic deployment, installation time and cost, market barriers, and policies in China“, Energy Policy, Vol.81, pp. 43-55, 2015. 